\title{
Preparing Graduates with Digital Literacy Skills Toward Fulfilling Employability Need in 4IR Era: A Review
}

\author{
Khuraisah $\mathrm{MN}^{1}$, Fariza Khalid ${ }^{2}$, Hazrati Husnin ${ }^{3}$ \\ Faculty of Education \\ Universiti Kebangsaan Malaysia \\ Bandar Baru Bangi, Malaysia
}

\begin{abstract}
This systematic review aims to review and synthesize employer expectations towards digital skills among graduates, steps, and measurements taken by higher education institutions to prepare students and harness motivation among students to make themselves competitive and marketable toward fulfilling employability needs in 4IR era. It was designed based on the Preferred Reporting Items for Systematic Reviews and Meta-Analyses (PRISMA). Articles published between January 2016 and 2020 were sought from three electronic databases: Science Direct, Scopus, and Web of Science. Additional items gain from the Universiti Kebangsaan Malaysia repository are also considered to be reviewed. All papers were reviewed, and the quality assessment was performed. Twenty articles were finally selected. Data were extracted, organized, and analyzed using a narrative synthesis. The review identified three overarching themes: (1) Employer perspectives on their expectation from young graduates. (2) Institutions' views on how they should prepare their students for the 4IR era. (3) Students' perspectives on how they could motivate themselves. The systematic review provides insightful information on the required digital literacy skills among young graduates, expectations of the industry player, and how digital literacies can be developed in the institutions.
\end{abstract}

Keywords-Digital literacy; computer literacy; information literacy; employability

\section{INTRODUCTION}

The Fourth Industrial Revolution (4IR) defined as a complete digitization process that connects orders from the customer and manufacturing up to the after-sales service [1]. The term attracted attention to many leading industry players after the World Economic Forum in 2016 and became influential agenda to many developed countries. The pace for 4IR is fast in comparison to the previous industrial revolution, thus cause disruptive innovation through all social systems [2].

It gave a broad impact on most current job characteristics, not least resulting in the loss of traditional jobs and creating a new job opportunity. To stay relevant in the job market, one needs to have skills and the will to learn and re-learn [3]. The new job field will focus more on non-routine activities and include higher cognitive levels and soft skills. Therefore, this is an important trait which graduates must fulfill to meet the need of employers and to make themselves relevant and marketable.

The process of preparing student marketability in higher institution education is significantly critical. Students today are extensively exposed to technology and used it in most of their daily undertakings [4]. This group is known as digital natives, a term introduced by Prensky [5]. However, does being born after the digital era make these generations automatically digital literate?

Kirschner and Bruyckere [6] believed that the term digital native is too general and can be questionable. Even though students of this generation are used to the ever-connected digital world, they may not always be able to utilize the current technology as expected entirely. There is a digital literacy gap between them, and this literacy gap needs to be identified and minimize during the study years, making the students well prepared for the employability.

\section{DigitAl Divide AND DigitAl LiterACY}

Previously, the digital divide defined as the gap between those who have access to computers and the Internet with those who do not. This gap arises due to several barriers, such as consumer socioeconomic factors, high technology access costs, and complex system interfaces [7]. Prior studies on the digital divide focused on demographic, socioeconomic, gender, and ethnic, which ultimately led to the "have or not have" computer and internet access as the foundation for their argument [5, 8, 9, 10].

However, even though more people have access to the Internet through smartphones, this does not mean that the digital divide has closed [11]. Previous findings show that members of minority groups, young people, low-income, and less educated are more dependent on smartphones. Tsetsi and Rains [12] claimed that dependence on smartphones might bridge the digital divide, but it caused another problem, which was the information gap. In this case, the new digital divide is no longer due to the availability or accessibility of the Internet. However, it does look at the differences in internet usage, namely, as a second-level digital divide [13].

"In the $21^{\text {st }}$ century, the term illiteracy no longer refers to those who do not know how to read and write, but it is to those who have not learned how to learn”. The excerpt is from 
Alvin Toffler's book Future Shock [12], an American author and futurist. Toffler, in his book, goes a long way, expecting that students will face too many options. Therefore, they should be taught how to perform the process of classification and reclassification of information, evaluate information, and be able to move abstract objects into concrete, and vice versa.

Focus is now not only on the issue of what one needs to know about technology but how the technology effectively and critically being utilized [14]. Additionally, able to evaluate the reliability of online content [15], and relate the information collected with the area of specialization [16]. Employers nowadays need digitally-savvy employees who can conduct their work effectively and seamlessly through everchanging technologies and emerging media [17].

Therefore, this review paper led to presume that digital literacy is a must-have skill for young graduates to make themselves employability ready. Thus, the systematic review provides insightful information on the required digital literacy skills among graduates, the expectation of the industry player, and how the development of digital literacies by the higher education institution identified at the end of this systematic review. Its help foster the understanding and add essential knowledge in preparing graduates toward fulfilling employability need in 4IR era.

\section{THE REVIEW}

\section{A. Aims}

This literature review has two aims. The first aim is to explore published research studies for digital literacy expectations and employability preparedness among graduates. The second aim is to review and synthesis the digital literacy skills needed by the students at higher education institutions to meet the requirements of employability in the 4IR era. The critical questions that the researchers want to answer are:

- What are the expectations among employers that the students need to fulfill?

- How does the institution prepare its students with digital literacy before graduate?

- How can the students be more motivated to improve their digital literacy?

\section{B. Design}

This review adapts and adopts a systematic approach and conducted in line with the Preferred Reporting Items for Systematic Reviews and Meta-Analyses (PRISMA) standard [18]. PRISMA used as a guideline to identify articles base on the pre-specified eligibility requirements as a framework for answering determine research questions. It allows the researcher to minimize biases by using explicit and systematic methods. The researcher then systematically read through each article and noting common themes on employer expectations, higher education institution preparation, and student's motivation toward development to join the job market.

\section{Search Strategy}

A Boolean search strategy was applied. Three electronic databases used, namely Scopus, Science Direct, and Web of Science. The keyword used is ("digital literacy” OR "technology literacy” OR “computer literacy” OR “information literacy”) AND (“employability”), with some different syntax according to the database used.

\section{Inclusion and Exclusion Criteria}

The first level of filtering method done by using the buildin refine option provided by each database used. The inclusion criteria were (1) articles published from January 2016 to 2020, (2) English and Malay language publication, and (3) document type: research article. The exclusion criterion was (1) 2015 and before, (2) using a language other than English and Malay and (3) document type conference, book, book chapter, and proceeding.

The second level of filtering method conducted manually by going through each title abstract before carefully determine whether to review the articles or reject it based on (1) material is a review paper (2) Population is not related to tertiary education (3) Not-in-line with research objectives (4) Specific for library literacy (5) Research Note.

\section{E. Search Outcomes}

In line with the Preferred Reporting Item for Systematic Reviews and Meta-Analysis (PRISMA) researcher adopt and adapts the steps and showing the process using Fig. 1, Article searching and filtering process using the systematic approach.

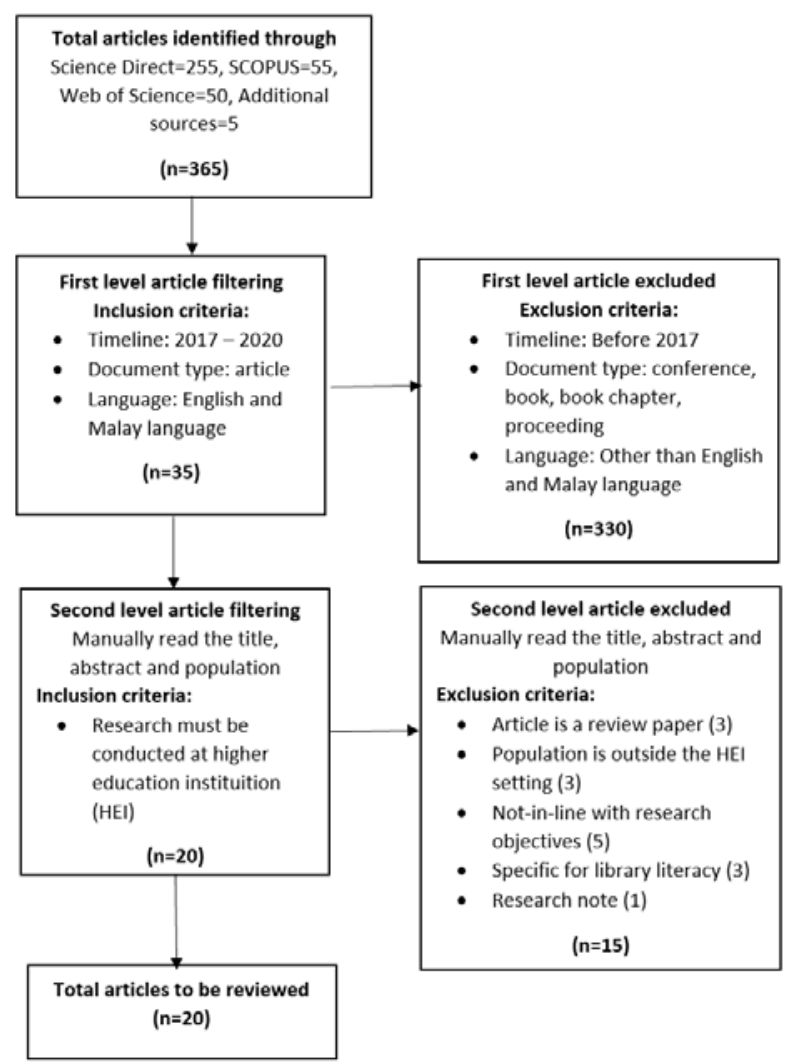

Fig. 1. Article Searching and Filtering Process using the Systematic Approach.

This study is conducted under GG-2019-068 grants. 
By using the specific search keyword, 365 articles identified. In the first level selection, only 35 items met the criteria. 330 articles excluded due to publication before 2016; documents are either conference, book, book chapter, or proceeding and published in a language other than English and Malay language.

In the second filtering phase, abstracts reading revealed 15 articles were irrelevant and not in-line with the current research objectives. Its include review paper, the population that is not related to higher education institution (HEI), specific for library literacy and research note.
These steps provide us with a systematic way to identify relevant literature for a review process. Finally, 20 articles were selected to be carefully read and synthesize their key findings to answer the research questions. The summary of the research articles is shown later in Table II.

\section{RESUlT AND DisCUSSIONS}

Table I shows the summary of the selected studies in terms of design, method, and location.

The research findings are structured according to the research questions and thoroughly discussed further details.

TABLE I. Summary of Types of Design, Method, AND SAMPle Of Selected ARTiCles

\begin{tabular}{|l|l|l|}
\hline Design & Method & Sample / Settings \\
\hline & Diary writing (1) & \\
& Phenomenology (1) & \\
Content Analysis (3) & Students (14) \\
Qualitative (8) & Exploratory (2) & Industry player (4) \\
Quantitative (7) & Case Study (1) & Academician (3) \\
Mix-Method (4) & Causal (1) & Others (3) \\
Action Research (1) & Confirmatory Analysis (1) & \\
& Reflective (2) & \\
& Interview (5) & \\
& Cross-sectional (1) & Time series (1) \\
& Multinomial logistic regression analysis (1) & \\
\hline
\end{tabular}

TABLE II. SUMmARY (IN DATE ORDER) RESEARCH ARTICLES INCLUDED IN THE REVIEW

\begin{tabular}{|c|c|c|c|c|}
\hline Study & Aim & Design/Method & Sample/Settings & Major Finding \\
\hline $\begin{array}{l}\text { The } \\
\text { employability } \\
\text { skills among } \\
\text { students of } \\
\text { Public Higher } \\
\text { Education } \\
\text { Institution in } \\
\text { Malaysia [19] }\end{array}$ & $\begin{array}{l}\text { This paper attempt to } \\
\text { shows the relationship } \\
\text { between employability } \\
\text { skills and demographic } \\
\text { data among graduates in } \\
\text { public universities of } \\
\text { Malaysia. Additionally, } \\
\text { the researcher is also } \\
\text { trying to proves other } \\
\text { impacting factors for } \\
\text { employability among the } \\
\text { graduates. }\end{array}$ & $\begin{array}{l}\text { A quantitative - cross-sectional } \\
\text { survey }\end{array}$ & $\begin{array}{l}554 \text { undergraduate } \\
\text { students throughout } \\
\text { several universities in } \\
\text { Malaysia. }\end{array}$ & $\begin{array}{l}\text { 1. The study raised the importance of the } \\
\text { institution to equip its students with } \\
\text { information-technology environment } \\
\text { friendly. } \\
\text { 2. The researcher emphasizes the need to } \\
\text { establish a good connection between } \\
\text { students and the industrial player by having } \\
\text { an internship program. } \\
\text { 3. Teaching and learning approaches, } \\
\text { facilities, and technology provided by the } \\
\text { institution must in-line with the industry } \\
\text { demands. }\end{array}$ \\
\hline $\begin{array}{l}\text { How does the } \\
\text { pedagogical } \\
\text { design of a } \\
\text { technology- } \\
\text { enhanced } \\
\text { collaborative } \\
\text { academic } \\
\text { course promote } \\
\text { digital } \\
\text { literacies, self- } \\
\text { regulation, and } \\
\text { perceived } \\
\text { learning of } \\
\text { students? [17] }\end{array}$ & $\begin{array}{l}\text { This paper focused on } \\
\text { learning processes that } \\
\text { enabled the development } \\
\text { of various digital } \\
\text { literacies conceptualized } \\
\text { by the Digital Literacy } \\
\text { Framework: photo- } \\
\text { visual, information, } \\
\text { reproduction, branching, } \\
\text { social-emotional, and } \\
\text { real-time thinking skills. }\end{array}$ & Qualitative - Diary writing & $\begin{array}{l}78 \text { ( } 82 \%) \text { out of } 95 \\
\text { students enrolled in four } \\
\text { consecutive semesters of } \\
\text { a graduate course in } \\
\text { education. }\end{array}$ & $\begin{array}{l}\text { 1. The study suggests self-regulation and } \\
\text { learning new technologies as an integral } \\
\text { part of digital literacies. } \\
\text { 2. The researcher recommends to include self- } \\
\text { regulation learning skills in the Digital } \\
\text { Literacy Framework. }\end{array}$ \\
\hline
\end{tabular}




\begin{tabular}{|c|c|c|c|c|c|}
\hline $\begin{array}{l}\text { Information } \\
\text { skills for } \\
\text { business } \\
\text { acumen and } \\
\text { employability: A } \\
\text { competitive } \\
\text { advantage for } \\
\text { graduates in } \\
\text { Western Sydney } \\
\text { [20] }\end{array}$ & $\begin{array}{l}\text { This paper aims to } \\
\text { identify the information } \\
\text { skills needed from the } \\
\text { graduate before they } \\
\text { enter the job market. } \\
\text { The researcher also } \\
\text { interested to look for } \\
\text { current literacy skills } \\
\text { thought in the university } \\
\text { that can be applied when } \\
\text { the student comes to the } \\
\text { industry. }\end{array}$ & $\begin{array}{l}\text { Qualitative - phenomenology } \\
\text { studies. }\end{array}$ & $\begin{array}{l}24 \text { participants, which } \\
\text { consist of } 12 \text { graduates } \\
\text { and } 12 \text { employers who } \\
\text { have experience of } \\
\text { supervising graduates. }\end{array}$ & $\begin{array}{l}1 . \\
2 . \\
3 . \\
\\
4 . \\
5 .\end{array}$ & $\begin{array}{l}\text { Researcher confirms that information skill } \\
\text { is a critical factor in competitive } \\
\text { workplaces; therefore, the ability to } \\
\text { evaluate information is the most valuable } \\
\text { skills. } \\
\text { Participants emphasized the importance of } \\
\text { information skills for individual endurance } \\
\text { and autonomy, especially in enabling } \\
\text { lifelong learning and adaptability. } \\
\text { Gathering information for problem-solving } \\
\text { is close to a real situation in the working } \\
\text { environment, thus engaging students in } \\
\text { more profound and active learning } \\
\text { opportunities. } \\
\text { Focusing on commonly used tools in the } \\
\text { industry may be helpful for new graduates. } \\
\text { Other essential skills needed by the industry } \\
\text { is a collaborative skill. }\end{array}$ \\
\hline $\begin{array}{l}\text { Student } \\
\text { Perception On } \\
\text { Graduate } \\
\text { Employability } \\
\text { In Era Of } \\
\text { Fourth } \\
\text { Industrial } \\
\text { Revolution [21] }\end{array}$ & $\begin{array}{l}\text { The objectives of this } \\
\text { study are to investigate } \\
\text { students' understanding } \\
\text { of 4IR and their } \\
\text { perception towards } \\
\text { graduates' employability } \\
\text { issues in this era. }\end{array}$ & $\begin{array}{l}\text { Quantitative - Exploratory } \\
\text { study }\end{array}$ & $\begin{array}{l}97 \text { respondent selected } \\
\text { using simple random } \\
\text { sampling among } \\
\text { students from the } \\
\text { Faculty of Economy and } \\
\text { Management, Universiti } \\
\text { Kebangsaan Malaysia }\end{array}$ & $\begin{array}{l}1 . \\
2 .\end{array}$ & $\begin{array}{l}\text { The main finding in this study shows that's } \\
\text { students have a fair understanding of } 4 \text { IR } \\
\text { and aware of the changes in the industry. } \\
\text { Results from the survey also show that } \\
\text { students must have the willingness to build } \\
\text { new skills to cope with the technology } \\
\text { changes. }\end{array}$ \\
\hline $\begin{array}{l}\text { Strategic } \\
\text { university } \\
\text { practices in } \\
\text { student } \\
\text { information } \\
\text { literacy } \\
\text { development } \\
\text { [22] }\end{array}$ & $\begin{array}{l}\text { The researcher aims are } \\
\text { to explore and } \\
\text { understand how } \\
\text { university practice has } \\
\text { an impact on the } \\
\text { development of } \\
\text { students' information } \\
\text { literacy. }\end{array}$ & Qualitative - interviews & $\begin{array}{l}31 \text { respondent from } \\
\text { various public research } \\
\text { universities in Malaysia } \\
\text { consists of students, } \\
\text { lecturers, and librarians. }\end{array}$ & $\begin{array}{l}1 . \\
2 . \\
2 . \\
3 . \\
4 . \\
5 . \\
4 . \\
\\
4 .\end{array}$ & $\begin{array}{l}\text { The most apparent findings in this paper } \\
\text { are the acknowledgment that lecturers, } \\
\text { librarians, students, and management all } \\
\text { play an essential part in developing } \\
\text { information literacy skills. } \\
\text { The inability to conduct independent } \\
\text { information searching and manipulation } \\
\text { will lead to a lack of problem-solving } \\
\text { skills. } \\
\text { The outcome-based learning approach will } \\
\text { motivate students to gather data from } \\
\text { different resources and then construct new } \\
\text { knowledge to meet their needs. } \\
\text { Applying various strategies in the teaching } \\
\text { and learning approach will develop student } \\
\text { information literacy skills. } \\
\text { Librarian suggests a collaborative } \\
\text { information literacy program development } \\
\text { between the library and academic } \\
\text { department will have a significant impact } \\
\text { on the development of information literacy } \\
\text { among students. }\end{array}$ \\
\hline $\begin{array}{l}\text { Redesigning } \\
\text { curriculum in } \\
\text { line with } \\
\text { Industry } 4.0 \\
{[23]}\end{array}$ & $\begin{array}{l}\text { This paper focused on } \\
\text { redesigning curriculum } \\
\text { and teaching practice, } \\
\text { in-line with the 4IR } \\
\text { trend. }\end{array}$ & $\begin{array}{l}\text { Qualitative method - content } \\
\text { analysis }\end{array}$ & $\begin{array}{l}72 \text { publications about } \\
\text { 4IR from 2013-2018 } \\
\text { using a strict filtering } \\
\text { process. }\end{array}$ & & $\begin{array}{l}\text { Universities need to be more determined to } \\
\text { equip the upcoming generation with the } \\
\text { skills related to capture, analyze, and } \\
\text { communicate data using IT infrastructures. } \\
\text { Propose Model Curriculum Matrix include } \\
\text { Big Data, IoT, Cloud Computing, AI, and } \\
\text { AR. }\end{array}$ \\
\hline $\begin{array}{l}\text { Employability } \\
\text { Skills Model for } \\
\text { Engineering } \\
\text { Technology } \\
\text { Students [24] }\end{array}$ & $\begin{array}{l}\text { This researcher seeks to } \\
\text { create a forecast model } \\
\text { for predicting the } \\
\text { chances of attaining } \\
\text { high-level employability } \\
\text { skills among students of } \\
\text { engineering technology. } \\
\text { By identifying missing } \\
\text { factors, the researcher } \\
\text { aims to reduce the } \\
\text { unemployment rate with } \\
\text { the introduction of an } \\
\text { invention program. }\end{array}$ & $\begin{array}{l}\text { Quantitative - multinomial } \\
\text { logistic regression analysis }\end{array}$ & $\begin{array}{l}\text { 1. } 204 \text { engineering } \\
\text { technology students } \\
\text { from various } \\
\text { technical } \\
\text { institutions chosen } \\
\text { using a random } \\
\text { sampling technique. }\end{array}$ & & $\begin{array}{l}\text { The result of this study indicates the ability } \\
\text { to use information technology in innovative } \\
\text { ways, extra-curriculum activities, and the } \\
\text { industrial-based program used to predict the } \\
\text { level of employability skills. } \\
\text { Study shows interesting factor identified } \\
\text { affecting employability skills among } \\
\text { graduates is parents occupational. }\end{array}$ \\
\hline
\end{tabular}




\begin{tabular}{|c|c|c|c|c|}
\hline $\begin{array}{l}\text { Changing skills } \\
\text { for architecture } \\
\text { students } \\
\text { employability: } \\
\text { Analysis of job } \\
\text { market versus } \\
\text { architecture } \\
\text { education in } \\
\text { Egypt [25] }\end{array}$ & $\begin{array}{l}\text { Researcher focus on } \\
\text { evaluating the } \\
\text { transferable skills } \\
\text { through two different } \\
\text { courses, namely: } \\
\text { (i) Architecture } \\
\text { Education course } \\
\text { (ii) Architecture, } \\
\text { Engineering, and } \\
\text { Construction } \\
\text { with the industry job } \\
\text { market in Egypt and to } \\
\text { propose an approach to } \\
\text { fill the gap between } \\
\text { both. }\end{array}$ & $\begin{array}{cl}\text { Mix method: } \\
\text { i. } & \text { Questionnaires } \\
\text { ii. } & \text { Interviews }\end{array}$ & 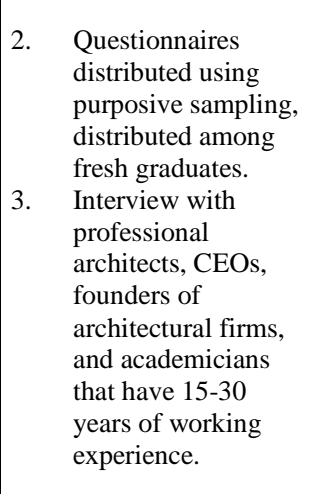 & $\begin{array}{l}\text { 1. Strong evidence shows that by applying } \\
\text { technology in teaching and learning } \\
\text { activities will encourage and help the } \\
\text { students to build their 21-century skills. } \\
\text { 2. The result of this study also indicates that } \\
\text { lecturers should give more flexibility and } \\
\text { empowered the students in coursework } \\
\text { development. } \\
\text { 3. Interestingly, the interview shows that } \\
\text { providing the students with an opportunity } \\
\text { to connect with the company, increasing } \\
\text { the timeframe of internship, promoting } \\
\text { academic exchange, and encouraging } \\
\text { participation in conferences in likely } \\
\text { increase students' employability rate. }\end{array}$ \\
\hline $\begin{array}{l}\text { The digital } \\
\text { culture of } \\
\text { students of } \\
\text { pedagogy } \\
\text { specializing in } \\
\text { the humanities } \\
\text { in Santiago de } \\
\text { Chile [26] }\end{array}$ & $\begin{array}{l}\text { This study aimed to } \\
\text { gather data that might } \\
\text { give prospective input } \\
\text { about teachers in a } \\
\text { humanities course that } \\
\text { come from the } \\
\text { millennial generation. } \\
\text { The researcher is } \\
\text { interested in } \\
\text { investigating whether } \\
\text { cyber-culture helps } \\
\text { future teachers using } \\
\text { digital technology even } \\
\text { though the humanities } \\
\text { course lacks technology } \\
\text { subject. }\end{array}$ & $\begin{array}{l}\text { Quantitative - Exploratory } \\
\text { research }\end{array}$ & $\begin{array}{l}118 \text { students of } \\
\text { Pedagogy in Secondary } \\
\text { Education selected } \\
\text { through a population } \\
\text { study and surveys with a } \\
\text { non-probabilistic } \\
\text { sample. }\end{array}$ & $\begin{array}{l}\text { 1. The result of this study shows a } \\
\text { technological transition has consequences } \\
\text { for initial teacher training. } \\
\text { 2. Teacher training should consider adapting } \\
\text { changes and new cultural conditions from } \\
\text { digital technology as a complement to the } \\
\text { educational process. }\end{array}$ \\
\hline $\begin{array}{l}\text { An exploratory } \\
\text { study of digital } \\
\text { workforce } \\
\text { competency in } \\
\text { Thailand [27] }\end{array}$ & $\begin{array}{l}\text { The researchers aim to } \\
\text { define the individual } \\
\text { skills desired by the } \\
\text { digital workforce, } \\
\text { whether the capabilities } \\
\text { of the digital workforce } \\
\text { can be group into } \\
\text { categories, and establish } \\
\text { the expectations of } \\
\text { demand for } \\
\text { competencies of the } \\
\text { digital workforce. }\end{array}$ & $\begin{array}{cl}\text { Mix method } \\
\text { i. } & \text { Qualitative- content } \\
& \text { analysis and } \\
& \text { interview } \\
\text { ii. } & \text { Quantitative } \\
& \text { Exploratory } \\
& \text { research }\end{array}$ & 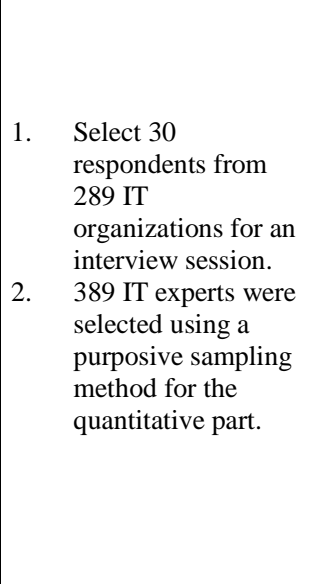 & $\begin{array}{l}\text { 1. The interview sessions suggest that types of } \\
\text { competencies needed by the digital } \\
\text { workforce are attitude, essential IT for } \\
\text { work, critical-thinking, general } \\
\text { communication, IT foundations, IT support, } \\
\text { lifelong-learning, problem-solving, and } \\
\text { teamwork. } \\
\text { 2. Based on the questionnaire survey, it helps } \\
\text { us to understand that competencies related } \\
\text { to soft skills and foundation knowledge in } \\
\text { IT are most required, followed by IT } \\
\text { technical ability and IT management } \\
\text { capabilities. } \\
\text { The most prominent finding emerges from } \\
\text { the interview session are, almost all IT } \\
\text { experts in Thailand expect graduates to } \\
\text { show skills in lifelong learning, personal } \\
\text { attitude, and dependable. }\end{array}$ \\
\hline $\begin{array}{l}\text { How the flipped } \\
\text { classroom } \\
\text { affects } \\
\text { knowledge, } \\
\text { skills, and } \\
\text { engagement in } \\
\text { higher } \\
\text { education: } \\
\text { Effects on } \\
\text { students' } \\
\text { satisfaction } \\
\text { Luis [28] }\end{array}$ & $\begin{array}{l}\text { The main objective is to } \\
\text { present a successful } \\
\text { flipped classroom } \\
\text { proposal in higher } \\
\text { education to understand } \\
\text { better its influence in } \\
\text { terms of knowledge, } \\
\text { skill, and engagement. }\end{array}$ & \begin{tabular}{ll}
\multicolumn{2}{l}{ Mix method } \\
i. & Qualitative - in-depth \\
& interview. \\
ii. & Quantitative - \\
& instruments \\
& development
\end{tabular} & $\begin{array}{l}\text { 1. Conduct an in- } \\
\text { depth interview } \\
\text { with senior and } \\
\text { knowledgeable } \\
\text { academic } \\
\text { scholars. } \\
\text { 2. } 160 \text { students } \\
\text { enrolled in the } \\
\text { Macroeconomics } \\
\text { module and the } \\
\text { dual-degree } \\
\text { program in } \\
\text { Management \& } \\
\text { Law and Business } \\
\text { Administration. }\end{array}$ & $\begin{array}{l}\text { 1. The finding of this study suggests a 4D- } \\
\text { FLIPPED Model that consists of out-of- } \\
\text { class activities, feedback, in-class activities, } \\
\text { and the use of technology. } \\
\text { 2. The researcher strongly emphasizes the } \\
\text { need for two-way feedback as an effective } \\
\text { way to link out-of-class activities and in- } \\
\text { class-activities. } \\
\text { 3. Additionally, the study results show that } \\
\text { technology usage help established lecture } \\
\text { outside of the classroom, thus creating more } \\
\text { active learning inside the school. }\end{array}$ \\
\hline
\end{tabular}




\begin{tabular}{|c|c|c|c|c|c|}
\hline $\begin{array}{l}\text { Building student } \\
\text { employability } \\
\text { through } \\
\text { interdisciplinary } \\
\text { collaboration: } \\
\text { an Australian } \\
\text { Case Study [29] }\end{array}$ & $\begin{array}{l}\text { The focus of this study } \\
\text { is to have an in-depth } \\
\text { understanding of the } \\
\text { importance of } \\
\text { information literacy to } \\
\text { develop employability } \\
\text { skills among students } \\
\text { through the capstone } \\
\text { project. }\end{array}$ & Qualitative - Case study & $\begin{array}{l}\text { Respondents are } \\
\text { Biological Sciences } \\
\text { capstone course students } \\
\text { at Macquarie University, } \\
\text { Sydney, Australia. }\end{array}$ & 2. & $\begin{array}{l}\text { Researcher finds that students give more } \\
\text { attention to discipline-specific literacy and } \\
\text { only give little attention to general } \\
\text { information literacy. } \\
\text { The results reveal a specific emphasis on } \\
\text { four dimensions of learning, namely self- } \\
\text { awareness, opportunity awareness, decision } \\
\text { making, and learning about the transition. }\end{array}$ \\
\hline $\begin{array}{l}\text { Classification } \\
\text { Techniques for } \\
\text { Predicting } \\
\text { Graduate } \\
\text { Employability } \\
\text { [30] }\end{array}$ & $\begin{array}{l}\text { The main objectives of } \\
\text { this research are to } \\
\text { identified factors } \\
\text { affecting graduate } \\
\text { employability. }\end{array}$ & Quantitative - time series & $\begin{array}{l}43863 \text { UKM graduates } \\
\text { data instance from the } \\
\text { Malaysia Ministry of } \\
\text { Education tracer study } \\
\text { year 2011-2017. }\end{array}$ & 1. & $\begin{array}{l}\text { The result from data tracer shows that age, } \\
\text { course, faculty, co-curriculum activities, } \\
\text { marital status, industrial training, and } \\
\text { English proficiency are the most influential } \\
\text { factors that determine graduate } \\
\text { employability rate. } \\
\text { However, studies show that the most crucial } \\
\text { factors are age, industrial training, and } \\
\text { faculty. }\end{array}$ \\
\hline $\begin{array}{l}\text { Information } \\
\text { Literacy in } \\
\text { Practice: } \\
\text { Content and } \\
\text { Delivery of } \\
\text { Library } \\
\text { Instruction } \\
\text { Tutorials [31] }\end{array}$ & $\begin{array}{l}\text { The focus of this study } \\
\text { is to analyze the content } \\
\text { of library tutorials and } \\
\text { match it with the level } \\
\text { of difficulties based on } \\
\text { Bloom Taxonomy. }\end{array}$ & Qualitative - content analysis & $\begin{array}{l}\text { Online tutorials made } \\
\text { publicly available } \\
\text { through academic library } \\
\text { web sites. The source for } \\
\text { tutorials for this content } \\
\text { analysis is the winners of } \\
\text { ACRL's Excellence in } \\
\text { Academic Libraries } \\
\text { Award. }\end{array}$ & 1. & $\begin{array}{l}\text { The result suggested that information } \\
\text { literacy competencies can be matched to } \\
\text { Bloom's Taxonomy under the first three } \\
\text { categories, namely remembering, } \\
\text { understanding, and applying. } \\
\text { The researchers suggest considering } \\
\text { developing higher-order thinking skills } \\
\text { when designing the online tutorial material. }\end{array}$ \\
\hline $\begin{array}{l}\text { Resignification } \\
\text { of educational } \\
\text { e-innovation to } \\
\text { enhance } \\
\text { opportunities } \\
\text { for graduate } \\
\text { employability in } \\
\text { the context of } \\
\text { new university } \\
\text { degrees [32] }\end{array}$ & $\begin{array}{l}\text { The researchers intend } \\
\text { to present innovative } \\
\text { teaching ways in higher } \\
\text { education institutions for } \\
\text { teaching methodologies } \\
\text { and how it's related to } \\
\text { employability ready } \\
\text { among the graduates. }\end{array}$ & Action research & $\begin{array}{l}\text { Undergraduate and } \\
\text { master's degree students } \\
\text { undertake two subjects: } \\
\text { i. } \quad \text { Event } \\
\text { Organization, } \\
\text { ii. } \quad \text { Protocol and } \\
\text { Institutional } \\
\text { Relations } \\
\text { Faculty of Economics } \\
\text { and Business, } \\
\text { University of Alicante, } \\
\text { Spain. }\end{array}$ & 2. & $\begin{array}{l}\text { Results demonstrate training program } \\
\text { allowed graduates to improve their } \\
\text { employability and career development } \\
\text { opportunities by encouraging active } \\
\text { participation and self-directed learning. } \\
\text { Participants believed technology literacy is } \\
\text { essential, and it is crucial to have a wide } \\
\text { range of skills and knowledge of digital } \\
\text { tools, especially ones related to } \\
\text { communication. }\end{array}$ \\
\hline $\begin{array}{l}\text { Employability } \\
\text { skills of } \\
\text { maritime } \\
\text { business } \\
\text { graduates: } \\
\text { industry } \\
\text { perspectives } \\
\text { [33] }\end{array}$ & $\begin{array}{l}\text { The focus of this study } \\
\text { is to investigate current } \\
\text { and future industry } \\
\text { employability skills for } \\
\text { maritime business } \\
\text { graduates. }\end{array}$ & Mix-method & $\begin{array}{l}\text { Conduct focus groups, } \\
\text { individual interviews, } \\
\text { and an online survey } \\
\text { with senior managers in } \\
\text { maritime organizations } \\
\text { from Australia, USA, } \\
\text { and Canada. }\end{array}$ & $\begin{array}{l}2 . \\
3 .\end{array}$ & $\begin{array}{l}\text { The most apparent finding that emerges } \\
\text { from the interview session is that maritime } \\
\text { business graduates must have excellent } \\
\text { communication skills, problem-solving, } \\
\text { adaptability, self-management, teamwork, } \\
\text { digital literacy, and technology literate for } \\
\text { them to be employable ready. } \\
\text { Noticeably that the maritime industry is } \\
\text { moving toward digitization, therefore } \\
\text { increase the demand for digital literacy and } \\
\text { technology knowledge and skills. } \\
\text { The survey shows that the use and } \\
\text { management of technology are the current } \\
\text { skills that maritime business graduate } \\
\text { focusing. }\end{array}$ \\
\hline $\begin{array}{l}\text { A new } \\
\text { educational } \\
\text { pattern in } \\
\text { response to new } \\
\text { technologies } \\
\text { and sustainable } \\
\text { development. } \\
\text { Enlightening } \\
\text { ICT skills for } \\
\text { youth } \\
\text { employability in } \\
\text { the European } \\
\text { Union [34] }\end{array}$ & $\begin{array}{l}\text { This paper aims to } \\
\text { identify the importance } \\
\text { of training in ICTs to get } \\
\text { a job. It intended to } \\
\text { analyze the relation } \\
\text { between ICTs' } \\
\text { knowledge and } \\
\text { employment for young } \\
\text { people in the European } \\
\text { Union. }\end{array}$ & Quantitative - Causal research & $\begin{array}{l}\text { Respondent age } 16 \text { and } \\
24 \text { years old at the } \\
\text { European Union. }\end{array}$ & 2. & $\begin{array}{l}\text { The importance of emphasizing informal } \\
\text { education on ICT is identified as an } \\
\text { essential element to be employment ready. } \\
\text { The researcher highlights the importance of } \\
\text { the promotion of self-learning environments } \\
\text { as well as the long-life learning in ICTs to } \\
\text { increase youth employability. }\end{array}$ \\
\hline
\end{tabular}




\begin{tabular}{|c|c|c|c|c|}
\hline $\begin{array}{l}\text { Motivational } \\
\text { factors } \\
\text { predicting ICT } \\
\text { literacy: First } \\
\text { evidence on the } \\
\text { structure of an } \\
\text { ICT motivation } \\
\text { inventory [35] }\end{array}$ & $\begin{array}{l}\text { This article focusses on } \\
\text { presenting the } \\
\text { construction and first } \\
\text { validation of an ICT } \\
\text { motivation inventory } \\
\text { based on social } \\
\text { cognitive theory. The } \\
\text { researcher intends to } \\
\text { predict computer-related } \\
\text { knowledge and skills, } \\
\text { deduced from ICT- } \\
\text { related usage motives, } \\
\text { self-effacing, and self- } \\
\text { regulation. }\end{array}$ & $\begin{array}{l}\text { Quantitative - Confirmatory } \\
\text { factor analyses }\end{array}$ & $\begin{array}{l}323 \text { German students } \\
\text { between } 16 \text { and } 27 \text { years } \\
\text { of age. }\end{array}$ & $\begin{array}{l}\text { 1. Significant findings of this paper have } \\
\text { developed the concept of ICT motivation, } \\
\text { measurement of motivation, and first } \\
\text { empirical results on the measure's } \\
\text { dimensional structure and construct } \\
\text { validity. } \\
\text { 2. Another critical finding is motivational and } \\
\text { metacognitive ICT characteristics are } \\
\text { essential for the acquisition and } \\
\text { development of ICT knowledge and skills. }\end{array}$ \\
\hline $\begin{array}{l}\text { Encouraging } \\
\text { student learning } \\
\text { of control by } \\
\text { embedding } \\
\text { freedom into the } \\
\text { curriculum: } \\
\text { students } \\
\text { perspectives } \\
\text { and products. } \\
\text { [36] }\end{array}$ & $\begin{array}{l}\text { This paper aims to look } \\
\text { at a novel mechanism } \\
\text { for encouraging students } \\
\text { to take more ownership } \\
\text { of their learning in terms } \\
\text { of control topics and } \\
\text { improve learning } \\
\text { engagement. }\end{array}$ & $\begin{array}{l}\text { Qualitative - Reflective } \\
\text { research }\end{array}$ & $\begin{array}{l}\text { Undergraduate } \\
\text { Bioengineering student. }\end{array}$ & $\begin{array}{l}\text { 1. The researcher proves that when the } \\
\text { lecturer assigns extensive usage of modern } \\
\text { technology within assignments, students } \\
\text { show enthusiasm to complete it. } \\
\text { 2. Another vital point is by encouraging } \\
\text { students to develop teaching materials is the } \\
\text { final part of the learning cycle will provide } \\
\text { a useful learning experience. }\end{array}$ \\
\hline $\begin{array}{l}\text { "Old school" } \\
\text { meets "new } \\
\text { school": Using } \\
\text { books and } \\
\text { tablets to } \\
\text { improve } \\
\text { information } \\
\text { literacy and } \\
\text { promote } \\
\text { integrative } \\
\text { learning among } \\
\text { business } \\
\text { students [37] }\end{array}$ & $\begin{array}{l}\text { This article aims to } \\
\text { discuss the use of an } \\
\text { ordinary book versus } \\
\text { tablet program and } \\
\text { highlight how these } \\
\text { programs can enhance } \\
\text { students' } \\
\text { communication and } \\
\text { collaboration skills, thus } \\
\text { enhance employability. }\end{array}$ & $\begin{array}{l}\text { Qualitative - reflective } \\
\text { research }\end{array}$ & $\begin{array}{l}\text { First-year business } \\
\text { students, Nipissing } \\
\text { University School of } \\
\text { Business, Canada }\end{array}$ & $\begin{array}{l}\text { 1. The study shows that a common book } \\
\text { program offers the potential for a variety of } \\
\text { activities that improve the students' literacy } \\
\text { and communication skills. } \\
\text { 2. The use of a tablet allows students to held } \\
\text { academic research during lectures and } \\
\text { efficiently communicate the information } \\
\text { with their classmates. } \\
\text { 3. The researcher believes that peer feedback } \\
\text { is an essential element of in-class research. }\end{array}$ \\
\hline
\end{tabular}

\section{EMPLOYERS: SKILLS NEEDED IN THE FOURTH INDUSTRIAL ERA}

Almost all areas of work in today's digital information societies require digital literacy skills. Competencies related to Information-Communication-Technology (ICT) are an integral part of employability [33, 20]. Considering the increasingly changing technological climate, self-regulated and lifelong learning are critical factors in keeping up with recent innovations in the industry [35].

Employers are not expecting fresh graduates to know everything when they begin their careers. Most of the employers are willing to train their newly recruit staff. Nevertheless, what they are looking for is the willingness to learn. Therefore it is safe to infer that self-learning is the most required skills by employers [20, 21, 25, 27, 28, 33, 34].

Today, we are living in an era where unlimited information is available and accessible. Locating and accessing data can be considered as lower-order skills, as these tasks are processbased and generally do not require students to analyze or synthesize information. Therefore, according to Saunders [31], the ability to evaluate sources and content would be considered as higher-order information skills. Graduates expected to be able to select, synthesize, and to leverage information in decision making. These skills will ultimately provide a competitive advantage to them [20, 22]. Another vital skill highly demanded among employers in this digitization era is analytical skills [20, 25, 33]. Employees were supposed to be able to think objectively, holistically, gather data, and evaluate it to support the decision-making process.

Communication skills are also pertinent [30]. Effective communication requires empathy, active listening, written, and verbal skills. Also, the employer expects the employee to have functional computer literacy, experience in the use of core computer application, and knowledge in data processing and information dissemination. Students graduating in this era must and should be able to communicate effectively in all electronic forms [33].

New media literacy and virtual collaboration are two additional critical skills needed in the future workforce. These skills will provide employees with the opportunity of integrating productivity-software or technology into their work and encouraging them to collaborate easily [34]. The collaboration skills is another expected skills required by the current industrial revolution era [17, 23, 29, 34, 37].

Minimize the gaps in soft skills is essential to many employers. Jewell [20] strongly recommended that higher education institutions improve communication, interpersonal and critical skills for students in classrooms. Also, the student 
should be allowed to choose suitable media when presenting the information they have attained, as this will nurture the students' soft skills gradually. Applying outcome-based learning could also encourage the student to construct knowledge, based on the information gathering activities [22].

According to Khodeir and Nessim [25], there are two quality categories among graduates, which are technical and non-technical skills. Universities seldom get a negative review of the technological capabilities of their students. Nevertheless, lack of employability skills among students is the critical reason for the frustration among employers. Similarly, Mang [37], in their research, found out that business graduates often become specialized in one particular area, but unable to relate it with world knowledge which is beyond their area of expertise. If graduates can combine highly develop meta-skills, it will provide them with more flexibility and lead to a successful career.

\section{INSTITUTIONS: PREPARING STUDENTS WITH DIGITAL LITERACY SKILLS}

Generally, the Higher Education Institution (HEI) is the last formal institution used to prepare students before they embark into the industry. Therefore, HEI must design its curriculum and nurture the needed skills during the students' study period.

However, Ayale-Pérez and Joo-Nagata [26] say that the millennial generation grown up with technologies. Therefore, even if their initial training in universities did not emphasize in the applied computer or computer-related subjects, this generation could still be able to work with technological products and services naturally. On the other hand, Mang [37] believed that today's ease of information access often provides students with a false feeling of competency. Even if they could easily find information, students cannot still critically evaluating the data. Therefore, nurture these skills must be during the studies period that is critically needed.

Whereas discipline-specific mastery is vital, exposure to integrated learning provides students with flexibility is also required in the industry [37]. Incorporating information and communications teaching in universities may be troublesome, but it will be beneficial in preparing students for the work market [34].

The student should be assisted in the development of mastery office computer applications to improve digital literacy among them. Assignment should be versatile, allowing students to select information services and approaches freely. Flexibility, experiential, and active learning are likely to involve students in more in-depth education, thereby improving the skills required in the industry [20].

Next, by adding more practical implications, real-life projects, and embedded digital literacy skills in the teaching and learning approach, it will encourage and assist students in building their digital literacy skills $[22,23]$. A method such as a flipped classroom will provide better exposure and influence in terms of knowledge, skills, and engagement to the students [28].
Furthermore, regardless of how familiar the digital natives with technology, one must admit that technological changes are so fast. Thus, doing continuous training is significant [34]. HEI needs to keep up with these trends and tried to embrace it in their teaching approach. Ellahi [23] suggested that a curriculum framework should encapsulate the elements of big data, Internet of things, cloud computing, artificially intelligent, and augmented reality, thus producing university graduates that meet the expectation of 4IR industry.

Another way to establish familiarity between study environment and job environment is by providing students with an internship program [19, 24, 30]. It is also the responsibility of the institution to offer excellent facilities and technology, in-line with the trend and demand of the industry player [19].

Based on the articles reviewed, it is noticeable that the responsibility of developing employability skills among students should not be limited in Information Technology classes. Instead, it can incorporate it in all subjects, in term of teaching approach and assignments design. Selecting appropriate technology to be used is the responsibility of both lecturers and students, supported by the institution. Only then, all the needed skills will be embedded in the student's mind organically.

\section{STUDENTS: MOTIVATION NEEDED TOWARD DEVELOPING DigITAL LiTERACY SKILLS}

The expectation among employers and preparation by the institution is only half the effort in preparing the students for employability. To survive the fast pace of the 4IR era, students need to have strong motivation towards developing skills required themselves.

Besides, when lecturers are more flexible and embracing their students in designing coursework, these will give students the feeling of empowerment. Students' empowerment would have a significant impact on them [17, 25, 32, 36]. It gave the ultimate motivation to learn by providing them with a reason to conduct a particular exploration. Also, setting autonomous goals and applying participatory educational approaches will foster critical thinking and the development of professional skills as needed in the industry [32].

Students need to play an active role in their learning. By doing so, they can acquire a series of abilities associated with content-knowledge education that will make them more desirable when they graduate [28].

Clearly, in the selected articles reviewed, self-motivation can be nurtured by giving students more power to explore and use a wide variety of technologies available. Students' empowerment will encourage engagement in their learning, therefore, making them more motivated to learn and explore. These characteristics of self-learning and willingness to learn are among the most desirable skills in the industry.

\section{AN EMERGING FINDING OF DIGITAL LITERACY}

Most activities using ICT by young adults nowadays are predominantly for entertainment and social interaction purposes, which including game playing and passive forms of 
media consumption such as video streaming. These ICTrelated activities do not require extensive technological or information-related knowledge and skills. Widespread usage in entertainment and social media interaction does not add to digital literacy skills [35].

Senkbeil \& Ihme [35] further stated that not all ICT activities, entertainment, and social interaction activities, in particular, enhance ICT knowledge and skills. Assumed based on the list of articles reviewed, experience with the information-related task, is a vital prerequisite to acquire functional ICT knowledge and then consider as digitally literate.

In measuring the digital literacy level, Blau et al. [17] utilize Digital Literacy Framework (DLF). Digital Literacy includes namely, social-emotional thinking by separately addressing communication issues, different levels of teamwork - psychological ownership towards a collaborative outcome. The research finding emphasized the importance of independent study in higher education and students' ability to tailor learning experiences to meet their individual needs. Therefore there is a need to include self-regulation learning skills in the DLF.

\section{CONCLUSION}

Based on the synthesis of literature selected, we can conclude that digital literacy not only focuses on technological literacy but more on how we use technology in decision making. The processes of developing digital literacy skills should not be limited to the library or computer classes. Instead, if lecturers could find exciting ways to encourage their students, as a native digital, students will develop the skill needed, intuitively. What the students need is a reason to do so.

As we are now moving toward the era of the fourth industrial revolution, employers expect graduates to have competencies related to ICT, able to do self-learning and excellent information skills that come together with analytical skills. When there is so much information available, know how to look for information is no longer appreciated. Instead, graduates expected to have the ability to select, synthesize and leveraging data in decision making. Other than that, the competency to communicate effectively using all suitable electronic form and the medium is also a vital skill.

The focus when facing the 4IR era is the acknowledgment that education institutions play an essential role in preparing and develop students' skills and knowledge to meets the demand of industrial players. Lecturers are encouraged to use and embed technology in the teaching approach. Students should be given more empowerment in designing assignments so that it will provide them with the motivation to look for various forms of information and exciting ways to deliver their findings. This skill will naturally prepare the students for employability. The fast pace of the 4IR era requires every stakeholder, including students, academic institutions, and industry players ready to face ever-changing technology and ways to do things with a strong will to learn and re-learn.

\section{ACKNOWLEDGMENT}

This study is conducted under GG-2019-068 grant.

\section{REFERENCES}

[1] M. Wilkesmann and U. Wilkesmann, "Industry 4.0 - Organizing Routines or Innovations ?,” J. Inf. Knowl. Manag. Syst., vol. 48, no. 2, p. pp.238-254, 2018.

[2] S. Xu, H. H. Yang, J. MacLeod, and S. Zhu, "Social media competence and digital citizenship among college students," Convergence, vol. 25, no. 4, pp. 735-752, 2019.

[3] S. Ra, U. Shrestha, S. Khatiwada, S. W. Yoon, and K. Kwon, "The rise of technology and impact on skills,” Int. J. Train. Res., vol. 17, no. sup1, pp. 26-40, 2019.

[4] S. Yong and P. Gates, "Born Digital: Are They Really Digital Natives ?," Int. J. e-Education, e-Business, e-Management e-Learning, vol. 4, no. 2, pp. 2-5, 2014.

[5] M. Prensky, "Digital Natives, Digital Immigrants Part 1," Horiz., vol. 9, no. 5, pp. 1-6, 2001.

[6] P. A. Kirschner and P. De Bruyckere, "The myths of the digital native and the multitasker,” Teach. Teach. Educ., vol. 67, pp. 135-142, 2017.

[7] D. E. Frederick, "The Fourth industrial revolution and the digital divide,” Libr. Hi Tech News, vol. 36, no. 7, pp. 12-17, 2019.

[8] N. Mohd Daud, C. Siong Choy, A. Aris, I. S. Mohamed, R. Kamarudin, and R. Zainuddin, "The effects of students' backgrounds and attitudes on computer skills in Malaysia," Int. J. Manag. Educ., vol. 1, no. October, pp. 371-388, 2007.

[9] S. Naidoo and J. Raju, "Impact of the digital divide on information literacy training in a higher education context," South African J. Libr. Inf. Sci., vol. 78, no. 1, pp. 34-44, 2012.

[10] S. Salam, M. Yang, A. Shaheen, M. Movahedipour, and J. Zeng, "ICT and students performance in Pakistan,” Hum. Syst. Manag., vol. 36, no. 4, pp. 277-284, 2017.

[11] A. J. A. M. van Deursen and J. A. G. M. van Dijk, "The digital divide shifts to differences in usage,” New Media Soc., vol. 16, no. 3, pp. 507526, 2014.

[12] E. Tsetsi and S. A. Rains, "Smartphone Internet access and use: Extending the digital divide and usage gap,” Mob. Media Commun., vol. 5, no. 3, pp. 239-255, 2017.

[13] A. J. A. M. van Deursen and J. A. G. M. van Dijk, "The first-level digital divide shifts from inequalities in physical access to inequalities in material access,” New Media Soc., vol. 21, no. 2, pp. 354-375, 2019.

[14] D. Buckingham, "Defining digital literacy: What do young people need to know about digital media?,” in Nordic Journal of Digital Literacy, vol. 2010, no. 4, VS Verlag für Sozialwissenschaften, 2010, pp. 59-71.

[15] G. Polizzi, "Digital literacy and the national curriculum for England: Learning from how the experts engage with and evaluate online content," Comput. Educ., p. 103859, 2020.

[16] C. Mang, N. Brown, and L. Piper, “'Old school' meets 'new school': Using books and tablets to improve information literacy and promote integrative learning among business students," Int. J. Manag. Educ., vol. 15, no. 3, pp. 449-455, 2017.

[17] I. Blau, T. Shamir-Inbal, and O. Avdiel, "How does the pedagogical design of a technology-enhanced collaborative academic course promote digital literacies, self-regulation, and perceived learning of students?," Internet High. Educ., vol. 45, no. December 2019, p. 100722, 2020.

[18] L. Shamseer et al., "Preferred reporting items for systematic review and meta-analysis protocols (Prisma-p) 2015: Elaboration and explanation," BMJ, vol. 349, no. January, pp. 1-25, 2015.

[19] M. Z. Abd Majid, M. Hussin, M. H. Norman, and S. Kasavan, "The employability skills among students of Public Higher Education Institution in Malaysia,” Malaysian J. Soc. Sp., vol. 16, no. 1, pp. 36-45, 2020.

[20] P. Jewell, J. Reading, M. Clarke, and L. Kippist, "Information skills for business acumen and employability: A competitive advantage for graduates in Western Sydney,” J. Educ. Bus., vol. 95, no. 2, pp. 88-105, 2020. 
[21] L. Wei Sieng and A. Noradilah, "Persepsi Pelajar Terhadap Kebolehpasaran Graduan dalam Era Revolusi Perindustrian 4 . 0 ( Student Perception On Graduate Employability In Era Of Fourth Industrial Revolution ) LAI WEI SIENG * \& NORADILAH AZIZ,” J. Pers. Pelajar, vol. 22, no. 2, pp. 121-127, 2019.

[22] A. K. Aidah, A. B. Kamariah, and M. S. Parilah, "Strategic university practices in student information literacy development," Psychol. Appl. to Work An Introd. to Ind. Organ. Psychol. Tenth Ed. Paul, vol. 4, no. 19, pp. 253-259, 2019.

[23] R. M. Ellahi, M. U. Ali Khan, and A. Shah, "Redesigning curriculum in line with industry 4.0,” Procedia Comput. Sci., vol. 151, no. 2018, pp. 699-708, 2019.

[24] A. K. Zatul Iradah and M. Siti Mistima, "Employability skills model for engineering technology students,” J. Tech. Educ. Train., vol. 11, no. 2, pp. 79-87, 2019.

[25] L. M. Khodeir and A. A. Nessim, "Changing skills for architecture students employability: Analysis of job market versus architecture education in Egypt,” Ain Shams Eng. J., , 2019.

[26] T. Ayale-Pérez and J. Joo-Nagata, "The digital culture of students of pedagogy specializing in the humanities in Santiago de Chile,” Comput. Educ., vol. 133, no. June 2018, pp. 1-12, 2019.

[27] V. Siddoo, J. Sawattawee, W. Janchai, and O. Thinnukool, "An exploratory study of digital workforce competency in Thailand," Heliyon, vol. 5, no. 5, p. e01723, 2019.

[28] L. R. Murillo-Zamorano, J. Á. López Sánchez, and A. L. GodoyCaballero, "How the flipped classroom affects knowledge, skills, and engagement in higher education: Effects on students' satisfaction," Comput. Educ., vol. 141, no. October 2018, 2019.

[29] S. Lin-Stephens et al., "Building student employability through interdisciplinary collaboration: an Australian Case Study Building student employability through interdisciplinary collaboration: An Australian Case Study," Coll. Undergrad. Libr., vol. 26, no. 3, pp. 234251, 2019.
[30] Z. Othman, S. W. Shan, I. Yusoff, and C. P. Kee, "Classification techniques for predicting graduate employability,” Int. J. Adv. Sci. Eng. Inf. Technol., vol. 8, no. 4-2, pp. 1712-1720, 2018.

[31] L. Saunders, "Information Literacy in Practice: Content and Delivery of Library Instruction Tutorials,” J. Acad. Librariansh., vol. 44, no. 2, pp. 269-278, 2018.

[32] R. M. T. Valdés, A. S. Soriano, and C. L. Álvarez, "Resignification of educational e-innovation to enhance opportunities for graduate employability in the context of new university degrees," J. New Approaches Educ. Res., vol. 7, no. 1, pp. 70-78, 2018.

[33] P. S. L. Chen, S. Cahoon, H. Pateman, P. Bhaskar, G. Wang, and J. Parsons, "Employability skills of maritime business graduates: industry perspectives,” WMU J. Marit. Aff., vol. 17, no. 2, pp. 267-292, 2018.

[34] J. Picatoste, L. Pérez-Ortiz, and S. M. Ruesga-Benito, "A new educational pattern in response to new technologies and sustainable development. Enlightening ICT skills for youth employability in the European Union,” Telemat. Informatics, vol. 35, no. 4, pp. 1031-1038, 2018.

[35] M. Senkbeil and J. M. Ihme, "Motivational factors predicting ICT literacy: First evidence on the structure of an ICT motivation inventory," Comput. Educ., vol. 108, pp. 145-158, 2017.

[36] J. A. Rossiter, L. Barnett, E. Cartwright, J. Patterson, N. Shorten, and J. Taylor, "Encouraging student learning of control by embedding freedom into the curriculum: student perspectives and products," IFACPapersOnLine, vol. 50, no. 1, pp. 12149-12154, 2017.

[37] C. Mang, N. Brown, and L. Piper, “'Old school' meets 'new school': Using books and tablets to improve information literacy and promote integrative learning among business students,” Int. J. Manag. Educ., vol. 15, no. 3, pp. 449-455, 2017. 